\title{
Beyond the Nickelodeon: Cinemagoing, Everyday Life and Identity Politics
}

\author{
Judith Thissen
}

For most people, even those of us who know better, the image of cramped dingy nickelodeons in Manhattan's Lower East Side ghetto stands as a symbol for cinema's emergence in America.

- Ben Singer ${ }^{\mathrm{I}}$

Few topics in American film history have generated more controversy than the question of who went to the movies during the crucial years that the cinema established itself as a national mass medium and the movies became one of the most enduring expressions of American culture. By I9Io, millions of Americans were fervent moviegoers. How did these early audiences shape the history of American cinema? And how did the cinema shape their lives? In the opening decade of the 2oth century, the United States was still a nation of immigrants. Were the movies a vehicle for diffusing Anglo-Protestant values and sensibilities, or did American film culture evolve as a counterpoint to middle-class leisure patterns and operate as an alternative public sphere? Did the cinema play a significant role in the Americanization of its immigrant patrons? And if so, in what ways? Since the I970s, the issue of early cinema's social and cultural orientation has frequently appeared at the forefront of film historiography.

Many of the contributions to this ongoing debate have, like my own work, focused on New York City. Here, I will first explain why this has been the case and how previous accounts of the nickelodeon period have shaped our understanding of the relationship between early cinema and its audiences - workers and immigrants in particular. Second, I will discuss the main insights derived from so-called revisionist scholarship, which has challenged the traditional picture of pre-Hollywood cinema as primarily working-class entertainment, and demonstrated that the middle classes sought to appropriate and control cinema well before the American film industry began to accommodate this more affluent audience by changing its signifying practices and opening picture palaces. Recent studies supporting the "embourgeoisement thesis" have revealed in great detail the complex ideological tensions at work in cinema's transition from a cheap amusement associated with workers and immigrants into a respectable entertainment medium suited for all classes. They concentrate primarily on the discourse 
and practices of the film industry, its allies (Progressive reformers) and critics (anti-vice crusaders, religious leaders and the like) but have omitted the workingclass and immigrant audience itself - those very people who have been identified time and again as the most fervent patrons of early American cinema. As a social historian, I am first and foremost interested in how the cinema fitted into the everyday life of "real people." As Richard Maltby has pointed out, for most audiences of American cinema "the primary relationship with 'the cinema' has not been with individual movies-as-artifacts or as texts, but with the social experience of cinema." ${ }^{2}$ To understand this social experience, I argue, we need to broaden our idea of reception to include the world outside the movie theater, ranging from the factory, the church and public meeting halls to other forms of entertainment such as dance halls, saloons and vaudeville shows. In other words, we need to engage with the social world at large. In my case study, which comprises the second part of this article, I apply a multifaceted socio-historical approach to early cinemagoing in the "Great New York Ghetto," which was the central focus of social and cultural life for the city's Yiddish-speaking Jews ${ }^{3}-$ a place from where styles and trends emerged that were replicated in other Jewish neighborhoods in Greater New York, and subsequently exported to immigrant Jewish communities across the United States.

\section{A True Theater of the People}

American film historiography has long assumed that early movie audiences consisted primarily of working people, many of whom were recent immigrants or first-generation Americans. This characterization of cinemagoing as a workingclass and immigrant pastime was shaped to a great extent by the period's own writings about the nickelodeon boom that hit the nation in 1907. Most of these narratives dealt with New York City. This comes as no surprise if we consider that the city had not only the highest number of nickelodeons, but was also the center of the American entertainment industry and the hub of national publishing. Moreover, as Giorgio Bertellini points out, "over the course of the second half of the nineteenth century, New York came to personify both the most dynamic manifestations and the most detrimental excesses of capitalist modernity." 4 As the largest and most ethnically diverse metropolis in the United States, the city developed into an "emblematic ethnographic field" for newspaper men, moral crusaders, settlement workers, and other investigators interested in the social and cultural dynamics of the new urban life style. ${ }^{5}$

Manhattan's Lower East Side captured their imagination in particular. The overcrowded tenement district with its "foreign" population of recently arrived immigrants from Southern Italy and Eastern Europe appeared profoundly different from the rest of the city, fascinating and threatening at the same time. In I89o, Jacob Riis' landmark publication How the Other Half Lives: Studies Among the 
Tenements of New York revealed the New York slums to America's middle and upper classes. Over the next decades, progressive reformers and city officials published dozens of reports on the district's social problems, ranging from child labor, poor living conditions to the allegedly corrupting influence of cheap amusements like commercial dance halls and variety shows. Building on the success of Riis, "How the Other Half Laughs" (I898) even offered the readers of Harper's Weekly a glimpse inside the large Yiddish legitimate playhouses, cheap variety shows, freak museums and saloons on the Bowery, the main axis of entertainment in lower Manhattan. Well into the 2oth century, muckraking journalists satisfied the curiosity of their readers with human interest stories about almost every aspect of immigrant culture and social life.

As early as 1907, the moving picture shows of downtown "Little Italy" and the "Hebrew quarter" became an object of ethnographic interest and were integrated into the practice of middle-class slumming - real or virtual. In these "stuffy little box-like theatres," Harper's Weekly explained, "the passer-by with an idle quarter of an hour on his hands has an opportunity to kill the time swiftly, if he is not above mingling with the hoi polloi. Likewise the student of sociology may get a few points that he could not obtain in a day's journey through the thronged streets of the East Side." ${ }^{6}$ Before long, the nickelodeons in downtown Manhattan became the key representatives of early film exhibition in New York, and even of the nation at large. In the public mind, the typical nickelodeon was a small, dark, smelly, ghetto storefront picture show overcrowded with poor, half-washed Jewish and Italian newcomers - a naive and impressionable audience eager to learn the American way of life from the silver screen.

Right from the first screenings of the cinematograph, the new film medium had been hailed as a universal language that could reach audiences across national, cultural and social boundaries. The metaphor of film as a universal language "emphasized connotations of egalitarianism, internationalism, and the progress of civilization through technology." "It was especially powerful in the United States, where a large part of the population was foreign-born and not yet fully integrated into the mainstream of American society. In The Art of the Moving Picture (I915), the poet Vachel Lindsay elaborated the notion of the movies as "American hieroglyphics" and stressed cinema's democratic nature and potential:

The invention of the photoplay is as great a step as was the beginning of picture-writing in the stone age. And cave-men and women of our slums seem to be the people most affected by this novelty. [...] The slums are an astonishing assembly of cavemen crawling out of their shelters to exhibit for the first time in history a common interest on a tremendous scale in an art form. ${ }^{8}$

Most Progressive reformers, including Jane Adams, John Collier and Mary Heaton Vorse, discussed in friendlier terms the popularity of motion picture entertain- 
ment with immigrant audiences and cinema's impact upon "the tired workers, overburdened men and women," who filled "the little halls throughout the city and throughout the land." Describing her visit to a nickelodeon on East Houston Street, Vorse wrote in I9II:

There they were, a strange company of aliens - Jews, almost all; haggard and battered and bearded men, young girls with their beaus, spruce and dapper youngsters beginning to make their way. In that humble playhouse one ran the gamut of the East Side. The American-born sat next to the emigrant who arrived but a week before. A strange and romantic people cast into the welter of the terrible city of New York, each of them with the overwhelming problem of battling with strange conditions and an alien civilization. And for the moment they were permitted to drink deep of oblivion of all the trouble in the world. ${ }^{9}$

Influenced by the ideas of Matthew Arnold, progressive reformers believed that education rather than repression was the answer to the deep social and cultural crisis that the United States faced as a result of the combined effects of mass migration, rapid urbanization and industrialization. As soon as the movies came into their purview, the nickelodeons were inscribed within a rhetoric of uplift. "The nickelodeon is the thing," John Collier of the People's Institute argued in a I908 article that appeared in Charities and Commons, a publication for social workers:

All the settlements and churches combined do not reach daily a tithe of the simple and impressionable fold that the nickelodeons reach and vitally impress every day. Here is a new social force, perhaps the beginning of a true theater of the people, and an instrument whose power can only be realized when social workers begin to use it. ${ }^{\text {Io }}$

The film historian Miriam Hansen found that articles in newspapers and popular journals abounded with clichés like "the poor men's elementary course in drama," "the academy of the working man," and "a grand social worker." ${ }^{\text {II }}$ Handed down by popular memory and traditional film histories, these stereotypical characterizations of early movie audiences and film exhibition in New York City generated the founding myth of Hollywood's democratic nature and the power of the cinema to change American society from the bottom up. For instance, in his influential study The Rise of the American Film (1939), Lewis Jacobs argued that from the outset:

The movies gave the newcomers, particularly, a respect for American law and order, an understanding of civic organization, pride in citizenship and in the 
American commonwealth. Movies acquainted them with current happenings at home and abroad. Because the uncritical movie-goers were deeply impressed by what they saw in the photographs and accepted it as the real thing, the movies were powerful and persuasive. More vividly than any other single agency they revealed the social topography of America to the immigrant, to the poor and to the country folk. ${ }^{\mathrm{I2}}$

Especially among historians on the left, pre-Hollywood cinema has been posited as a fundamentally progressive institution. For Jacobs and Garth Jowett ${ }^{13}$ the nickelodeon stood as a symbol for the close affinity between the "melting pot" ideology of the movies and the upwardly-mobile aspirations of its core audience. Robert Sklar, meanwhile, understood the cinema as a vehicle for working-class cultural and political agency. His Movie Made America - an exemplary work of I970s New Left historiography - opens with the statement that the movies were "the first of the modern mass media, and they rose from the surface of cultural consciousness from the bottom up, receiving their principal support from the lowest and most invisible classes in American society." ${ }^{14}$ Some twenty years later, Ben Singer provided new empirical evidence to support Sklar's assessment of the working-class nature of early film culture in urban America (Cinema Journal, 1995). ${ }^{15}$ His analysis of film exhibition in the nickelodeon era in Manhattan led to an extensive exchange on methodology that complicated the notion of class, but largely ignored questions about the ethnic background of early American movie audiences. Despite the insights gained from the mid-Iggos Manhattan nickelodeon debate, Working-Class Hollywood: Silent Film and the Shaping of Class in America (1998) by Steven Ross maintained that the American film industry was built with the nickels and dimes of working-class men, women and children, however open to question this now was. ${ }^{16}$ Whether inscribing the cinema within a scenario of Americanization (Jacobs, Jowett), or defining it as a site of hegemonic struggle over cultural power (Sklar, Ross), at the heart of this "democratic lineage" is an assumption about class: that cinemagoing in the United States was initially and essentially a working-class pastime. ${ }^{17}$

\section{The Embourgeoisement Thesis}

In the context of the breakthrough of the New Film History, revisionist film scholars had begun to challenge the traditional one-dimensional account of cinemagoing during the pre-Hollywood era, drawing attention to the significant contributions that the middle classes made to the transformation of the cinema into a mass medium. ${ }^{8}{ }^{8}$ Robert C. Allen's much-cited case study of film exhibition in Manhattan during the nickelodeon era, initially published in Cinema Journal in 1979, marked a turning point in the academic debate about early American movie audiences. ${ }^{19}$ Using previously overlooked sources such as business directories 
and fire insurance maps, Allen discovered that film exhibition in New York City was far from uniform. The Lower East Side storefront nickelodeons, "so beloved of film historians," were indeed small and "almost certain proletarian and immigrant oriented. ${ }^{\prime 2}$ However, Allen found that only a third of the movie theaters in Manhattan were located in working-class and immigrant neighborhoods. The low density of nickelodeons in immigrant neighborhoods other than the Lower East Side suggested considerable differences between ethnic groups and across town. In traditional entertainment districts like Union Square/East Fourteenth Street and the Herald Square area, large-capacity playhouses offered moving pictures and live acts in more or less equal proportions for a price lower than "high class vaudeville" and only slightly higher than the nickelodeons. According to Allen, these so-called "small-time vaudeville" theaters played a key role in upgrading exhibition conditions and building a middle-class audience for the movies. Moviegoing during the nickelodeon era, he concluded, was "by no means an exclusive activity of the poor or the immigrant." ${ }^{21}$

The revisionist interpretation of pre-Hollywood cinema consumption was absorbed without much debate into the mainstream of film historical scholarship. ${ }^{22}$ Since then, studies by Richard Abel, Lee Grieveson, Miriam Hansen, Sumiko Higashi, Janet Staiger, William Uricchio and Roberta Pearson (among others) have refined our understanding of the hegemonic strategies that the American film industry employed to create a modern mass entertainment culture and the struggles for cultural power and social control that went with it. ${ }^{23}$ Their work has broken away from unilateral top-down and bottom-up models of cultural transmission to offer a more complex picture of cultural change in which hegemonic intentions are negotiated and reshaped in various ways. Historians of American silent cinema usually acknowledge that workers and immigrants might have resisted the industry's efforts to impose middle-class standards of spectatorship. However, for the most part they deal with these "marginalized forces" only theoretically, and primarily from the perspective of the dominant institutions. Much of the research on early film audiences relies heavily on the film trade press and discourses of cultural elites, often combined with textually extrapolated notions of spectatorship that bring to light the bourgeoisification of taste evident through analyses of editing, performance, and narration. The concrete responses of working-class and ethnic communities to the industry's gentrification efforts, on the other hand, have received little attention. Notable exceptions are Bertellini's work on cinema and Italian Americans, and Jacqueline Najuma Stewarts' study of African American film culture. ${ }^{24}$ Language barriers partially explain this blind spot, but not completely. As Bertellini remarks, the problem is also that film historians "have tended to subsume immigrants rather quickly into the category of workingclass patrons," thereby disregarding the specific culture and historical trajectory of these groups, including their relation to their homeland. ${ }^{25}$ 
Consider the example of Hansen's Babel \& Babylon: Spectatorship in American Silent Film (I99I) as it centers on cinema's significance for social groups that were excluded from dominant formations of public discourse. Hansen analyzed the process of homogenization that accompanied the rise of corporate Hollywood and the ways in which spectators participated in, or resisted, this process. ${ }^{26}$ Drawing on Oskar Negt and Alexander Kluge, she argued that cinema functioned as a nonhegemonic, alternative public sphere for marginalized groups like women, workers and immigrants. However, according to Hansen, this function cannot be measured in any positive empirical sense. It can only be inferred from the force of negation, that is, from the industry's "hegemonic efforts to suppress or assimilate any conditions that might allow for an alternative (self-regulated, locally, and socially specific) organization of experience." 27 Consequently, Hansen's arguments rely almost entirely on analyses of the dominant bourgeois discourse of consumer capitalism as articulated by products of that discourse, namely films and reviews. However relevant this work may be to a general theoretical understanding of working-class and immigrant audiences, it ultimately tells us little about how cinemagoing fitted into their lives as a whole, or the ways in which cinema might have functioned (or not) as an agent of Americanization and upward social mobility. Moreover, Hansen's textually extrapolated thesis, that the nickelodeons constituted an autonomous public sphere in which working-class immigrants exercised collective authority over their moviegoing experience, requires more detailed historical probing. In the words of Gregory Waller, "before we can make any claims about the capacity of local communities to resist or customize mass culture," we first need to find out much more about how "commercial entertainment was packaged, promoted and consumed locally." ${ }^{28}$

\section{Cinema and Everyday Life}

In recent years, film historians have given increasing attention to the material conditions of film exhibition and consumption, and the ways in which these conditions structured the experience of actual moviegoers - "real people" - as opposed to hypothetical spectators. ${ }^{29}$ To be sure, the conception of a historical audience will "always and inevitably" remain to some extent "a construction and an abstraction," as Frank Kessler points out. ${ }^{30}$ Yet, this does not imply that historians should restrict themselves to theorizations of spectatorship. By investigating how film exhibition varied locally and across time, and by examining the practices of cinemagoing within their larger cultural and socio-economic contexts, we can clarify the conditions of reception and make historical claims about how the cinema figured in the lives of specific categories of consumers and what "going to the movies" meant to them.

Roy Rosenzweig's groundbreaking Eight Hours For What We Will: Workers \& Leisure in an Industrial City, 1870-1920 (I983) and Gregory Waller's Main Street Amuse- 
ments: Movies and Commercial Entertainment in a Southern City, 1896-1930 (I995) both offer compelling models for such localized, micro-historical reception studies. ${ }^{3 \mathrm{r}}$ Focusing on the city of Worcester (Massachusetts) and drawing on a wide range of evidence, Rosenzweig examines how recreational patterns changed as market forces invaded working-class entertainment and the city's middle and upper classes increasingly sought to impose their own standards of propriety and decorum on working-class recreation, which they often saw as challenging the dominant culture. He demonstrates that from the saloon, public park and July Fourth celebration to the movie theater, workers struggled to retain control over their leisure time and space. These struggles, however, did not necessarily unite workers, since they were often internally divided (typically along ethnic or religious lines) and employers manipulated these intraclass divisions to their own advantage. Whereas Rosenzweig covers a wide range of working-class amusements, including non-commercial leisure activities, Waller concentrates on commercial entertainment and puts the cinema at the center of his study. He realigns film exhibition (ownership, management style, theater design, programming practices, and marketing schemes) and reception (the way the community received the cinema, and its response to specific films) to position cinema and cinemagoing in the broader political, socioeconomic, and cultural context, exploring such issues as the fear of imported entertainment, notions of high and low culture, and the public articulation of moral values.

Waller makes full use of local and social historical approaches, as do many studies of cinema culture outside America's largest cities. With the turn towards micro-history, American film historiography has recently shifted to the study of cinemagoing in small towns and rural communities in the United States, which seem more apt subjects for case studies than the great cities. While this reorientation was much needed, it seems to go hand in hand with a certain blindness to the fact that we still know very little about how the cinema fitted into the social and cultural structure of ethnic communities in Manhattan, let alone Brooklyn or the Bronx. ${ }^{32}$ As the most popular locus of early American film historiography and American Jewish memory, the Lower East Side ghetto offers a prime site to explore how the social experience of the cinema was positioned between the poles of working-class bonding, ethnic community enhancement and Americanization.

It should be remembered that first-hand evidence documenting the meaning that ordinary people attached to their lives outside the workplace is still rare. However, an in-depth understanding of the recreational demands and preferences of Jewish immigrant workers can be obtained by examining the business strategies of the showmen who sought to amuse them. Their exhibition practices and marketing strategies are well documented by a wide range of evidence, including advertisements and articles in Yiddish-language press, trade reports, and social surveys by settlement workers. In combination with the discourse of Jewish immigrant intellectuals on popular entertainment, and municipal records relating 
to the actual buildings that were used as moving picture theaters, these sources reveal much about the kinds of pressures film exhibitors were under to remain in business, and thus shed a light on the pastimes and amusements of immigrant Jews and their changing attitudes and tastes in the realm of leisure.

Like the East Side nickelodeon, the mythology of early American cinema has turned the Jewish nickelodeon manager into a popular stereotype in his own right - chiefly because several Hollywood moguls began their careers in the moving picture industry as nickelodeon owners. Their road to success from humble immigrant origins to becoming captains of industry still stands as a symbol for the Jewish pursuit of the American Dream. Yet, if we want to understand moviegoing on the Lower East Side, the careers of the three New York moguls - Loew, Fox and Zukor - are not the best starting point. From the start, their business strategies aimed at conquering the mainstream middle-class market. Contrary to what is generally believed, it was not the nickels and dimes of the East Side Jews that propelled them to the top of the American film industry. Fox never ventured below East Fourteenth Street. Loew's flagships on the Lower East Side - the Avenue B and Delancey Street theaters - were built with the profits made in the city's traditional entertainment districts. By contrast, the career of Charles Steiner (I883-1946) offers a different model of Jewish showmanship. Steiner fashioned a niche in the nation's largest movie market by catering explicitly to Jewish working-class audiences in immigrant neighborhoods. In the remainder of this article, I will detail the first years of Steiner's career. What he programmed in his theaters and how he marketed his shows reveals much about how movies were consumed on the Lower East Side. To understand the logic of Steiner's early success is to learn how the cinema became the favorite entertainment pastime of immigrant Jews. ${ }^{33}$

\section{The Archetypical Nickelodeon}

Steiner's motion picture career began in 1908, when he turned his father's livery stable at 133 Essex Street into a storefront 250-seat nickelodeon. We can only speculate why the Steiners stepped into the film exhibition business. Father and son might have been impressed by the hundreds of people flocking every day to the Golden Rule Theater around the corner. The motion picture shows flourished, but many businesses suffered from the severe financial depression that followed the stock market crash of 1907. On the Lower East Side alone, more than one hundred thousand men and women were out of work (over $25 \%$ of the labor force). The recession forced increasing numbers of Jewish immigrants to abandon the Yiddish theaters and Yiddish music halls for cheaper forms of entertainment. The Jewish Daily Forward, the leading Yiddish newspaper, explained: 


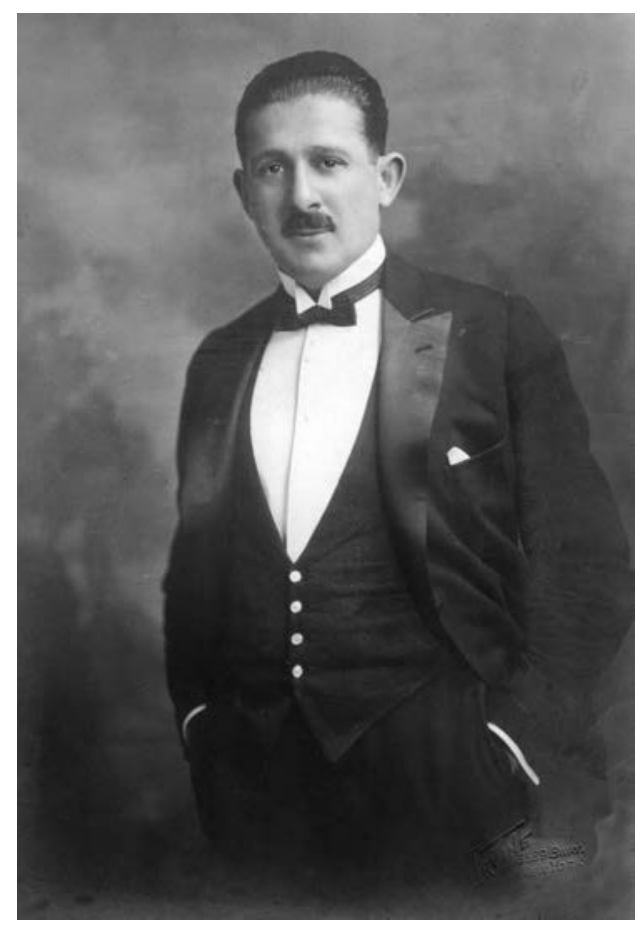

Fig. 1: Charles Steiner, circa 1925. Photo courtesy: Stoney Shukat.

In order to forget the troubles, misery and sadness, the best thing is to amuse yourself. [...] To go to the Yiddish theater costs at least a quarter, that is, when you take a seat on the gallery. This is a considerable sum of money in a time of economic recession. Especially when you have to treat a girl or a cousin, or your wife - then, it becomes a rather big expense. So people go to the "moving pictures." There you sit for five cents like a lord, and if you are lucky, you get a seat in a box near the stage, in one of those houses which were once music halls. ${ }^{34}$

In other words, the depression fueled the demand for cheap entertainment and the concomitant expansion of storefront picture shows. In April 1908, daily attendance at moving picture shows in New York City was estimated at three to four hundred thousand..$^{35}$ By the end of that year, at least thirty motion picture theaters were in operation in the downtown Jewish quarter, not counting those on the nearby Bowery and East Fourteenth Street. In addition to the favorable business circumstances created by the economic recession, the structural conditions for opening a nickelodeon in the heart of the Jewish quarter were excellent. Centrally located, this was one of the most congested parts of New York City. Many blocks in the area, which was known as the Tenth Ward, had over 3,000 inhabitants. In 
I902, the Tenement House Department found that almost ten thousand people lived in the four blocks forming the intersection of Rivington Street and Essex Street. ${ }^{36}$

Steiner's Essex Street Theater opened its doors in March I908. Mollie Hyman, who patronized the picture show as a little girl just after the opening, vividly remembered that "it used to be a stable, and inside the smell [of horses] was still there." 37 This childhood souvenir is one of the rare recollections we have about moviegoing in the Jewish quarter. Whereas the popularity of the Yiddish stage and its stars has been extensively recorded by Jewish-American memoir literature, most autobiographies and oral histories overlook the presence of the nickel-anddime movie theaters that were spread all over the Lower East Side. In retrospect, the movies seem to have been exclusively associated with American culture and hence ignored, while the Yiddish theater became the quintessence of the OldWorld flavored immigrant culture of the turn-of-the-century and the subject of much nostalgic reminiscence. Likewise, cinemagoing was so much part of everyday life that there are very few photographs of moving picture theaters. Hence, we have to dig deep in the records of the Bureau of Buildings and the Office of the City Register (where documents concerning property transfers and ownership are kept) to find information about their architecture, seating arrangements and interior design.

No detailed descriptions or floor plans of the Essex Street Theater have survived, and the building was demolished in I9I4 to make way for the 6oo-seat Palace Theater. However, an inventory, which was listed in a lease of I9I2, suggests that Steiner's first venture fitted the expectation of an "archetypal" storefront picture show as we know it from the standard accounts of the nickelodeon era:

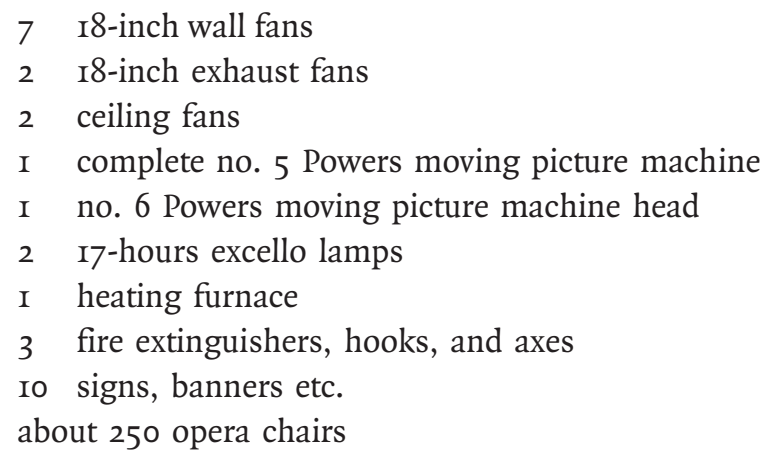

electric globes, glassware and all electrical wiring and lamps ${ }^{38}$

Despite the rather shabby setting, Steiner respected the fire regulations and kept this modest theater clean and ventilated. When an inspector of the National Board of Review visited the picture shows in the area, he found no fault with the 
Essex Street theater, whereas the nearby Golden Rule and WACO theaters were criticized for bad ventilation and sanitation. ${ }^{39}$

What did Mollie Hyman and other patrons see at the Essex Street Theater? Until mid-rgo9, most five-cent theaters in the Jewish quarter offered primarily moving pictures with "a song and a dance, as an extra," perhaps a sketch or two but without much scenery or props. ${ }^{40}$ If they offered more elaborate acts, the admission price might go up to ten cents in the evening and at the weekend. Unfortunately, we have very little information about the actual programs that were presented. Film exhibitors did not spend money on newspaper advertising for their shows. Only once did an advertisement for the Essex Street Theater appear in the Yiddish press. This simply pointed out that for five cents prospective patrons could expect the "finest moving pictures" as well as "fine singers and good artists." ${ }^{4 \mathrm{I}}$ Steiner and his immediate competitors typically used bill-boards, posters and handouts to reach the public, which according to the ticket seller of the WACO was "entirely local, confined almost within two or three blocks." "We play to our trade," he explained:

We have here the same people day after day, and we find out what they want and give it to them. The most elaborately produced Shakespearean plays don't appeal much to them; they don't understand them. Neither does the broad comedy that they like over in Fourteenth Street. What our patrons like most is sentiment and emotionalism that appeals to their better nature.

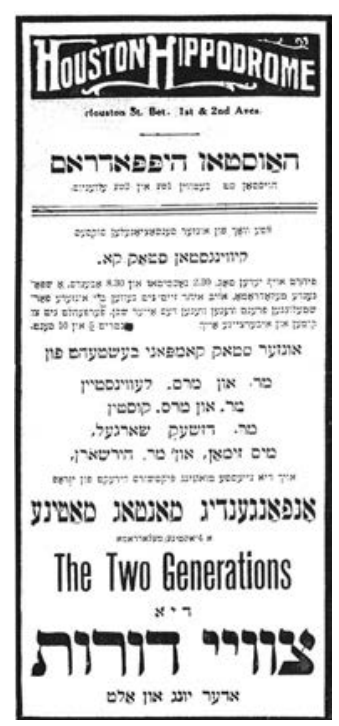

Fig. 2: Advertisement for the Houston Hippodrome, Jewish Daily Forward, 17 November 1912. 
In any case, patrons were more likely to watch European productions than American movies because until the early IgIos, the American market was dominated by European companies, especially Pathé Frères. ${ }^{43}$ Scattered evidence suggests that Jewish immigrant audiences showed a preference for sensational melodrama and tragedies with unhappy "Russian endings." The most successful Yiddish plays of this period, popular melodrama as well as literary plays, contained numerous heartbreaking scenes. The Forward cynically remarked that even:

When a manager of a Yiddish theatre decides to produce a comedy, he adds a couple of pogroms, some suicides, a few poor orphans, and a deserted woman - of course -, to make sure that the people will weep more than they will laugh. ${ }^{44}$

A contemporary observer noted that the programs in the East Side nickelodeons were typically built up as follows: "first a comic scene is shown, then the 'curtain' is raised and the 'artists' come, then again a comic scene, and at last a 'tragedy' with a moralizing ending." 45 From the same source we learn that in early I908, a show typically lasted half an hour, but if it was not very busy, one could stay for a couple of hours. During weekday afternoons attendance was small, but at night "they keep the theatre well filled in shifting relays," a reporter of the New York Sun explained, pointing out that "these are working people." ${ }^{46}$ In general, attendance peaked on weekday nights between 8 and II p.m., on Friday nights, and throughout Saturday and Sunday.

\section{A Combination Place}

As soon as Steiner had gained some initial experience in movie presentation, he expanded his business. In late I908, he formed a partnership with an exhibitor named Gordon and launched a second nickelodeon at 158 Monroe Street, in a former kosher sausage factory. For reasons unknown, the Monroe Street Theater was short-lived. ${ }^{47}$ Steiner's next project was more ambitious. A former church on East Houston was for sale. After its abandonment as a house of worship, Jack Rose, a minor figure in organized crime, had operated the building for some time as the Houston Athletic Club and given prize fights there. Steiner realized that the old but spacious building could easily be redesigned into a theater.

His partner in this venture was Abraham Minsky (I882-I949), the oldest of the legendary Minsky brothers, who were to become leading burlesque producers in the $1920 \mathrm{~s} .{ }^{48}$ With a couple of minor renovations the former church was transformed into a moving picture and vaudeville theater. According to Morton Minsky, no money was invested "into redecorating or refurbishing the old church." 49 The religious scenes had already been painted over by the former leaseholder and there was a small platform that could serve as stage. The pews on the ground 
floor and on the balcony could easily accommodate up to five hundred people..$^{\circ}$ Patrons used "the racks that once held hymnals" for storing the "bagels, salamis and other eatables they brought with them for nourishment during the long program," Morton Minsky remembered..$^{51}$ Eating and drinking was part of the informal atmosphere that characterized Jewish ethnic entertainment. It was also an additional source of income for the management. In the Yiddish music halls, which had their roots in concert-saloons, patrons could order beer and wines at the bar in the auditorium or in an adjacent saloon. Sometimes hot food was also served on the premises. Steiner and other film exhibitors who had started out during the nickelodeon era maintained no ties with the liquor trade or restaurant business. In their establishments only non-alcoholic beverages and confectionaries were served. At Steiner's Essex Theater, one Abraham Mazel paid a fee that gave him "the privilege of selling candies, soda water, ice cream etc." in the auditorium. ${ }^{52}$ Similarly, there was a small kosher dairy restaurant in the basement of the Houston Hippodrome, where patrons who had not brought along their own provisions, could eat a snack before or after the show, if they did not go for a knish to Yonah Shimmel's bakery next door. Shimmel, "original since I9Io," as the sign informs us today, survived from a time when movie theaters and inexpensive kosher dairy restaurants clustered together on the Lower East Side to serve Jewish working-class audiences.

Steiner and Minsky had chosen the perfect moment to launch a "vaud-pic" theater. The economy was recovering and most Yiddish music halls, which had turned to moving pictures as their staple entertainment during the recession, were switching back to fully-fledged vaudeville shows and higher admission prices. Nickelodeon operators, who until then had offered little more than a few jokes, illustrated songs, or at most a simple sketch to entertain the audience when the reels were changed, also began to add more and longer vaudeville acts to their bills. Steiner seized on the latest trend without delay. Even before the Forward acknowledged the "resurrection of the Yiddish music halls" in its theater special of 25 December 1909, he had opened his own "yidish englishe vodevil hoyz un muving piktshurs." 53 The explosive demand for Yiddish vaudeville had created a new entertainment tier between the moving picture show and the conventional Yiddish music hall, which the Forward defined as the kombineyshon plats:

[This is] a combination of a moving picture show and a music hall. For one nickel they offer, besides moving pictures, a few "single turns" - songs or dances, sometimes both. Some of these places have begun to present one and three act sketches. The entire company in these combination houses consists of no more than a few actors. ${ }^{54}$

The Houston Hippodrome was one of the first combination houses. We could see the format as a cut-rate small-time vaudeville house: patrons paid a nickel in the 
afternoon and a dime at night and on weekends. By contrast, established Yiddish vaudeville theaters such as the People's Music Hall and Agid's Clinton Vaudeville House charged up to thirty-five cents for their best evening seats and a minimum of a dime for matinee and gallery seats. Steiner and Minsky kept production costs down by hiring less famous Yiddish variety actors as well as amateur talent and by offering fewer headline acts and more moving pictures than the music halls. Also, they kept the theater open from II a.m. until I2 p.m. The Yiddish music halls offered only two shows per day (matinee and evening).

\section{Steiner's Advertising Scheme}

In sharp contrast to Steiner's advertising strategy for the Essex Street Theater, newspaper advertisements played a major role in the marketing of the Houston Hippodrome. In part, this helped to construct the image that the Houston Hippodrome was one of the finest amusement places in the downtown Jewish quarter, despite its popular prices. Newspaper advertising also helped Steiner and Minsky reach a much wider audience including, "business men and workers" who lived in other parts of the city. ${ }^{55}$ Its location near the ist Street station of the Second Avenue elevated train meant that theater was within easy reach of uptown Jewish neighborhoods, especially Jewish Harlem and the Bronx.

The first advertisements for the Houston Hippodrome were placed in the conservative Yidishes Tageblatt. However, Steiner and Minsky rapidly switched over to the more cosmopolitan press, especially the Jewish Daily Forward (Forverts). This socialist newspaper held a key position in the Jewish media landscape. Under the editorship of Abraham Cahan, one of the most prominent intellectuals, novelists and political activists of the immigrant generation, the Forward had set itself the task of guiding the Jewish working-class on the road to a cautious Americanization by building bridges between Jewish traditions and modern American culture. On many occasions, Cahan's editorials drew up guidelines for the immigrant Jewish community, telling readers what kind of behavior was appropriate and what was not, thus enhancing the image of the Forward as an authority on urban living. To boost circulation, Cahan never hesitated to capitalize on the inherent sensational character of show business news. Notwithstanding his sometimes fierce criticism of their "commercialism" and "corrupted" moral standards, theater managers were well aware that Cahan's marketing strategies matched their business interests, and hence considered the Forward to be the most attractive newspaper to promote their activities. The large Yiddish legitimate playhouses bought advertising space every day, whereas the Yiddish music-halls frequently publicized their program in the Forward. Until the late I9Ios, most film exhibitors considered that hand-outs and posters were sufficient means to attract patrons. But Steiner, who had a talent for marketing, understood that by advertising in the Yiddish press, he could differentiate his theater from the competition and attract 
a larger audience than the people who lived in the immediate surroundings of East Houston Street. Moreover, by deciding to promote the Houston Hippodrome in the entertainment section of the Forward, Steiner and Minsky positioned their new theater within the confines of the established Yiddish entertainment business.

Whereas the Yiddish music halls and the legitimate theaters presented the readers primarily with down-to-earth, straightforward information about the acts and actors on the bill, the announcements of the Houston Hippodrome were imbued with a quality that Jewish immigrants commonly referred to as "American bluff." To suggest the superiority of his shows, Steiner invariably spoke in superlatives. One week the Houston Hippodrome presented "the best act ever produced in vaudeville," the next week it featured the "biggest sensation of the season," and the week thereafter it had the "latest and newest moving pictures." The informal, conversational tone of the advertisements had to create a context of credibility for these hearty self-endorsements:

\section{Did you ever pass an afternoon or evening at the \\ Houston Hippodrome? \\ Not yet? Then don't wait, come when you want and stay as long as you want!}

We have the best vaudeville program, as well as the finest and newest moving pictures.

All this for five and ten cents admission

If you appreciate good actors, read the following names and admire our staff

Gentlemen: Mr. Kuperschmidt, Gilrod, Tuchband, Wolf, Siegel

Ladies: Miss Tuchband, Steinberg, Erven, Greenbaum and Cohn

Tell all your friends to meet you at the Houston Hippodrome,

$$
\text { I4I-I43 E. Houston St. }{ }^{56}
$$

Steiner injected great vitality into the prevailing style of entertainment advertising, combining a tone of neighborly chat and exaggerated self-endorsement. His publicity campaigns were characterized by a lively involvement with the public. Frequently, the advertisements not only drew attention to the program, but also congratulated the audience on its good taste:

Do you know that this is the greatest amusement place on the whole East Side? Do you know that the Houston Hippodrome company has the best actors of the Yiddish stage? If you don't know this, then come and see our great rich Pesach program, you will recognize at once that what we advertise is the whole truth and nothing but the truth. ${ }^{57}$

This congenial style of conversation and frequent use of direct address, a distinctive feature of Steiner's advertisements throughout the IgIos, followed naturally 
from the atmosphere of informality and relaxed socializing that characterized the early moving picture shows. As Roy Rosenzweig points out, "the early movie theater placed all customers on an equal plane," whereas legitimate playhouses and many other forms of cheap entertainment, including the Yiddish music halls, stratified patrons according to their ability to pay. "The lack of seating differentiation by price at the early movie houses exemplified its egalitarian social style," Rosenzweig notes..$^{58}$ Indeed, what accounted for the difference in admission price at the Houston Hippodrome was not the seating arrangement but the time of arrival: "afternoon 5 cents - evening ro cents." 59

\section{Programming Practices}

Significantly, the Houston Hippodrome advertisements focused almost exclusively on the program's main vaudeville attractions, providing little to no information about the films, except for such typical slogans as "also the latest and best moving pictures" and "our pictures are changed every day." Just once we learn that it offered "the best Biograph and Pathé moving pictures."60 Often it was not even mentioned that moving pictures were part of the bill. The programs lasted about an hour and a half, except on Sunday when shows were often shortened to capitalize on the increased demand. Vaudeville routines occupied about half of the program. Audiences were presented with a broad live entertainment program including comic sketches, dramatic scenes, one-act plays, songs and dances, and some kind of "sight act": a juggler, acrobat or an animal act. The vaudeville bill for the week of I9 December I909, a typical one for that season, featured "Hilda the Swedish handcuff queen," Mr. and Mrs. Schwartz in Elye-Hano'vi oder fishke, the "famous Italian opera singer Signor Pannini" with a selection of popular opera tunes and "Mr. Wernik with today's latest sentimental songs." ${ }^{\text {I }}$ Each item on the bill possessed broad crossover appeal, yet individual acts targeted a specific segment of the audience. For instance, Yiddish-language sketches such as the one about Elye-hano'vi (the prophet Elijah) aimed especially at the immigrant generation, while Mr. Wernik's English songs probably attracted the American-born youth. The moving pictures appealed to all ages. In other words, there was something for everybody on the program to ensure attendance across generational boundaries. $^{62}$

During the IgIO-II season, in a context of increased competition between the established Yiddish music halls and newly-opened combination places like the Houston Hippodrome, Steiner and Minsky also began to stage three-act plays. The publicity suggests that the new format aimed explicitly at a working-class audience:

The management of the Houston Hippodrome spares no trouble or expense to offer the public genuine plays for an admission price of five and ten cents. 
Every patron, who cannot afford to pay 50 or 75 cent to see a good play, will be given the opportunity to amuse himself and his family with Religion and Love, one of the best works ever performed. ${ }^{63}$

Each week a new play opened at the Houston Hippodrome. They were written in Yiddish and performed by local Yiddish stock companies consisting of six to eight actors. Most of these works were probably "adaptations" from the established Yiddish vaudeville stage, which in turn often copied material from the legitimate Yiddish theater. ${ }^{64}$ In the months of November and December 1912, the following titles appeared on the program: The Forced Marriage, Two Generations, Back from Siberia, Tears of an Orphan and The Trip to America. These titles suggest that most plays portrayed the challenges of immigration and Jewish life in the New World: poverty, vice, generational conflicts, soured marriages, and broken homes. In the same way, titles like Kain and Abel, The Jewish Queen, and The Thora Crown highlighted the Jewish nature of the subject matter. In sum, most programs at the Houston Hippodrome bore a direct relationship to the social and historical experience of its patrons.

Parallel to offering ever more elaborate stage shows, the Houston Hippodrome advertisements began to promote Jewish themed films. For instance, in the first week of November 1912, audiences could enjoy a ghetto drama about "a rabbi's daughter who marries a Christian lawyer." To increase its box-office appeal, this film had been retitled Di Yidishe Kroyn (The Jewish Crown) after Boris Thomashefsky's smash hit at the nearby National Theater. ${ }^{65}$ Three weeks later, the bill featured DER GENGSTER, portraying "the life of the East Side gangs." In later years, Steiner consistently singled out movies that dealt with Jewish themes, featured Jewish stars, or had strong ties with Eastern Europe. As I have argued elsewhere, a strong appeal to Yiddishkayt formed the cornerstone of his marketing strategy well into the $1920{ }^{67}$

At the end of 1912, Steiner and Minsky moved their vaudeville troupe to the National Winter Garden. This lavish I,ooo-seat roof-top theater with its gold and rose interior was situated above Thomashefsky's National Theater, where it occupied the upper floors of the building. Electric elevators took patrons up to the sixth floor, which was the orchestra level. Steiner and Minsky marketed their new venue as "a regular Broadway palace with popular admission prices." ${ }^{68}$ For ten cents in the afternoon and fifteen cents at night, prospective patrons were promised "high-class vaudeville in Yiddish and English and the best moving pictures," including at least one multi-reel feature. The Winter Garden opened with "RESURRECTION by L. N. Tolstoy," a four-reel production starring Blanche Walsh (Masko Film Company, I912). ${ }^{69}$ The theater's marketing campaign, programming and price structure strongly suggest that Steiner and Minsky had decided to enter into competition with Loew's for the patronage of the Jewish immigrant middle class. Despite the absence of conclusive empirical evidence, it is obvious that they 
miscalculated. The more affluent immigrant audience stayed away, despite the refined settings and feature films. The National Winter Garden's first season ended in failure. Within less than two weeks after the opening, Steiner and Minsky lowered the ticket price for the evening seats from fifteen to ten cents to make their theater more attractive for a working-class clientele. Soon after that, they ceased advertising. The advertisements for the Houston Hippodrome were also discontinued. By January 1913, its operation had been downgraded to that of an ordinary five-cent picture show. With a continuous program of moving pictures and no elaborate vaudeville acts - the archetypical nickelodeon format - there was no need for newspaper advertising.

\section{Film and Vaudeville}

Until I913, when changing legislation and a new rigid licensing process put an end to inexpensive "vaud-pic" combination theaters like the Houston Hippodrome, mixed-bill shows were highly successful on the Lower East Side. Bertellini has noted a similar pattern for the Italian immigrant community. Cafés-chantants and music halls were the dominant exhibition context in which films were shown in New York's downtown and uptown Little Italy. As Bertellini points out, "films were not an autonomous form of amusement. Rather, they constituted a new and appealing offering within the well-established variety format of Italian American small-time vaudeville houses." ${ }^{\circ \circ}$ What accounts for this interest that immigrant audiences took in the variety format?

Miriam Hansen has argued eloquently that the variety format offered structural conditions around which "working-class and ethnic cultures could crystallize, and responses to social pressures, individual displacement, and alienation could be articulated in a communal setting." ${ }^{7 \mathrm{I}}$ Vaudeville acts and sing-alongs encouraged a participatory mode of reception and active sociability between audience members. In addition, the use of the vernacular reinforced feelings of belonging to an immigrant community with shared values and a communal history. More importantly, perhaps, vaudevillians - very much like today's stand-up comedians - often tapped into the current political affairs for their material, addressing strikes, immigration policies etcetera, as well as the everyday hardships of tenement life and sweatshop work. ${ }^{72}$ In combination with the participatory quality of the variety format, these acts permitted working-class audiences to express their commitment to intraclass or ethnic solidarity, and nurture their own interpretation of "America" - one that did not necessarily conform to the dominant ideology of American citizenship and national identity.

It should be emphasized in this context that the heyday of ethnic vaudeville within moving pictures theaters coincided with the efforts of the American film industry to reposition cinema as a respectable American entertainment for all Americans, rather than a cheap amusement which relied heavily on foreign im- 
ports and catered primarily to workers and immigrants. According to Hansen, the emergence of "spectatorship" - the spectator as a structural term anticipated by the film - evolved as a crucial part of the industry's strategy to turn the cinema into a national mass entertainment medium: "The concept of spectatorship made it possible to precalculate and standardize individually and locally varying acts of reception, to ensure consumption across class, ethnic and cultural boundaries."73 Put differently, the film text rather than the theatrical experience had to become the prime site of meaning. Non-filmic activities that aimed at building audiences on the basis of a shared ethnic or working-class identity blocked the absorption of the individual viewer into the fictional world because they drew the viewer's attention to the social, cultural and physical space of the movie theater itself, thus emphasizing the value of the show as a collective experience. As Hansen points out, from I909 onwards, film exhibitors were urged to reduce live entertainment, especially vaudeville acts. This is precisely the moment when East Side film exhibitors began to include more ethnic entertainment into their programs, thus preserving early film-viewer relations, determined less by the film itself than by the context of reception. To be sure, film exhibitors like Charles Steiner did not offer Yiddish vaudeville because they believed in defending Jewish cultural heritage against Americanization, but because they expected to earn more money with mixed-bill shows. Even so, Yiddish vaudeville contained the Americanizing agency of the silver screen by shaping the reception of the films that were shown. It was only through repressive legislation that ethnic vaudeville disappeared from the bills of working-class cinemas in New York City. In I9I3, a new code for motion picture exhibition was passed by the Board of Aldermen. This Folk's Ordinance contained provisions that aimed directly at suppressing inexpensive vaudeville shows, while it encouraged film exhibitors in working-class districts to open medium-sized, purpose-built movie theaters where live entertainment was restricted to music. ${ }^{74}$

\section{Conclusion}

Revisionist scholarship has convincingly demonstrated that in a brief span of years prior to World War I, middle-class social and cultural anxiety led to a bourgeoisification of the American film product. However, as my case study makes clear, cinema's cultural and social ascendance throughout these years was an uneven development. Jewish nickel-and-dime theaters on the Lower East Side neither played out the embourgeoisement scenario nor fostered the simple assimilation of their working-class patrons into the American mainstream. Bertellini's research on cinemagoing in New York's downtown and uptown Little Italy also challenges the prevailing notion of a fast and consensual process of Americanization and gentrification. Albeit in different ways, both immigrant groups fostered a cinema culture that was closely embedded in older forms of ethnic 
amusements. In the absence of comparative data from other urban working-class communities and research on middle-class moviegoing in metropolitan contexts, it is difficult to make any larger generalizations. Moreover, in the early 2oth century, the American working-class experience remained an intensely local and predominantly ethnic experience. It may well be that the cinema played a crucial role in breaking up this insularity. To determine that, we would need to know more about working-class and middle-class film culture in the I920s and 1930s. Only at the intersection of diachronic and synchronic comparisons can we begin to fully understand the complexity of cinema's transformative impact upon American audiences. 